\title{
Использование генетических методов на основе ДНК-маркеров продуктивных признаков в селекции кур
}

\begin{abstract}
Коршунова Л.Г., доктор биологических наук, главный научный сотрудник отдела генетики и селекции Карапетян Р.В., кандидат биологических наук, старший научный сотрудник отдела генетики и селекции ФГБНУ Федеральный научный центр «Всероссийский научно-исследовательский и технологический институт птицеводства» Российской академии наук (ФНЦ «ВНИТИП» РАН)
\end{abstract}

\begin{abstract}
Аннотащия: Рассмотрены последние данные исследований по использованию 6 селекиии молекулярногенетических маркеров, сбязанных с продуктибными признаками кур. Показана бажность изучения полиморфизма генов, аллельные варианты которых ассоциированы с хозяйственно-полезными признаками птицы, для повышения эффректибности отечественного птицебодства. Проанализированы перспективные гены-кандидаты, непосредственно участвующие 6 рормировании того или иного продуктивного признака и имеющие варианты генетического полиморфизма. Исследованные гены-маркеры могут служить помощниками 6 отборе птиць для дальнейшего разбедения и селекции с целью закрепления желательных генотипов 6 отечественных породах кур.
\end{abstract}

Ключебые слова: куры, хозяйственно-полезные признаки, молекулярно-генетические маркеры, генетический полиморфизм, гены-кандидаты, локусы количественных признаков (QTL).

Современное птицеводство это динамичная, высокотехнологическая отрасль. Промышленное птицеводство, базирующееся на небольшом количестве высокопродуктивных линий и кроссов кур коммерческих пород, имеет свои минусы из-за снижения генетического разнообразия, приводящего к ограничению дальнейшей селекции по продуктивным признакам и снижению устойчивости к инфекциям ввиду гомозиготности по большому количеству генов и, как следствие, к снижению адаптивной способности организма. В настоящее время отечественные селекционеры сосредоточены на генетических аспектах с целью превращения генетического потенциала в реальные породы, породные группы и кроссы птицы. Создание новых отечественных пород и кроссов в условиях возрастающих требований к качеству и ассор- тименту птицеводческой продукции зависит от наличия генетического разнообразия всех видов сельскохозяйственной птицы.

В связи с этим выявление и использование молекулярно-генетических маркеров, связанных с продуктивностью, в практической селекции является актуальным как для фундаментальной, так и для прикладной науки [1,2]. Генетические маркеры представляют собой одно из последних достижений ДНК-технологий, которые открывают новые возможности в селекции. Маркер-ассоциированная селекция (MAS) - это современное перспективное направление в животноводстве, позволяющее эффективно использовать выявленные гены-маркеры хозяйственно-полезных признаков для повышения эффективности селекционной работы. В основе маркерной селекции лежит изучение полиморфизма различ- ных целевых генов в связи с продуктивными признаками. В принципе, исследования можно разделить на два этапа. На первом этапе проводится изучение генетической структуры исследуемой популяции, породы, кросса по целевым генам с целью определить полиморфизм конкретных локусов (генов), так как в случае мономорфности локуса провести отбор особей разных генотипов невозможно. В случае полиморфности исследованного локуса можно переходить к изучению связи полиморфизма по целевым маркерам с продуктивными признаками. Результаты можно использовать в селекции с целью получения потомства с желательными генотипами, которые характеризуются оптимальными значениями интересующих исследователя показателей: яичная и мясная продуктивность, качество яйца и т.д. 
Большинство хозяйственно ценных признаков домашних животных имеет сложный полигенный тип наследования и контролируется многими генами, расположенными в локусах количественных признаков (QTL). Изучение молекулярной организации QTL представляет интерес с точки зрения общей генетики, а данные о нуклеотидных последовательностях из районов QTL могут быть использованы для селекции на основе полиморфных вариантов генов, определяющих проявление важных в практическом отношении свойств. У кур одним из таких признаков служит толщина скорлупы яиц [3]. У двух пород кур разных направлений использования (яичная род-айленд и неспециализированная польская зеленоногая) методом полимеразной цепной реакции (ПЦР) в реальном времени провели анализ экспрессии 12 генов-кандидатов контроля хозяйственно значимого признака - толщины скорлупы яйца. У птицы породы польская зеленоногая выявлены достоверные различия между группами с тонкой и толстой скорлупой по уровню экспрессии последовательности CR523443 [4,11]. Таким образом, авторы установили, что последовательность CR523443 может рассматриваться как генкандидат, участвующий в контроле толщины скорлупы яйца у кур. Это дает инструмент для поиска однонуклеотидных полиморфизмов, влияющих на количественные признаки, которые можно использовать как молекулярные маркеры в практической селекции [3,4].

Изучение связи полиморфизма генов, аллельные варианты которых ассоциированы с хозяйственно-полезными признаками птицы, важно для повышения эффективности отечественного птицеводства. Перспективными ге- нами, непосредственно участвующими в формировании того или иного продуктивного признака и имеющими варианты генетического полиморфизма, являются гены, кодирующие регуляторные белки, в частности, гормон роста, пролактин и их рецепторы. Эти гормоны обладают различными регуляторными функциями. Гормон роста принимает участие в регуляции роста и дифференцировке различных тканей организма. Пролактин у птиц связан с функцией воспроизводства. Рецепторы являются необходимыми звеньями в цепи регуляций функций гормонов. Были проведены исследования генетической структуры различных пород кур по локусам гормона роста, рецептора гормона роста, пролактина, рецептора пролактина с целью определения связи между аллельными вариантами перечисленных генов и яичной продуктивностью. Выявлены достоверные различия в показателях продуктивности у особей с разными генотипами по изученным локусам [5]. Полученные авторами данные показывают, что генетическая дифференциация опытных популяций кур по совокупности изученных полиморфных локусов определяется, в первую очередь, типом продуктивности птицы, хотя степень влияния этого фактора может различаться. Наличие выраженной генетической изменчивости в изученных породах позволяет вовлекать их в направленную селекционную работу с использованием типирования особей по ряду QTL, чтобы получать экспериментальные линии с определенным набором желательных генотипов и их сочетаний [5].

Актуальны исследования по выявлению генетического полиморфизма в генах, связанных с формированием мышечной массы. К ним относятся гены миоста- тина, пролактина, рецептора D2 дофамина и ряд других. Один из наиболее информативных ген миостатина (MSTN), который является отрицательным регуляторным фактором роста, так как ингибирует синтез различных мышечных белков, в том числе сократительных, вследствие чего формирование и развитие скелетных мышц значительно замедляется. Ген миостатина обладает высоким уровнем полиморфизма. В разных участках этого гена обнаружены однонуклеотидные замены, отличающиеся частотой встречаемости в различных популяциях кур [6]. Было выявлено, что одиночный нуклеотидный полиморфизм имеет взаимосвязь с продуктивными качествами у кур отечественной селекции [7,8]. Авторы проанализировали популяцию кур юрловской голосистой породы по двум однонуклеотидным заменам в гене миостатина. Определили частоту встречаемости генотипов и аллелей по каждой замене, изучили связь замен с продуктивными показателями кур. В результате авторы пришли к выводу, что найденные две однонуклеотидные замены - G/А в положении 2109 и G/С в положении 2244 миостатинового гена - могут быть генетическими маркерами, но не причинными мутациями для признаков [7].

Проведены исследования по изучению экспрессии генов-кандидатов, участвующих в метаболизме липидов, с целью выявления в них полиморфизма и определения связи с содержанием абдоминального жира у кур мясного направления продуктивности $[9,10]$. Основываясь на функциональных характеристиках генов, связанных с похожими признаками у других животных, авторы отобрали 9 генов, являющихся функциональными кандидатами для массы абдоминального жи- 
pa: FABP1, FABP2, FABP3, HMGA1, MC4R, PPARG, PPARGC1A, POMC и PTPN1. С использованием метода ПЦР в реальном времени был исследован уровень экспрессии этих генов-кандидатов, оказывающих влияние на массу и содержание жира в тушке бройлеров (абдоминальный жир), в жировой ткани, печени, кишечнике, мышцах, гипофизе и головном мозге. Были обнаружены достоверные различия экспрессии генов HMGAl и PPARG в печени «жирных» и «нежирных» бройлеров [10].

Сегодня предлагается широкий спектр ДНК-чипов для генотипирования животных. Благодаря их активному использованию в геномах были обнаружены вариации числа копий - CNV (copy number variation), которые изменяют экспрессию генов и оказывают влияние на фенотипические признаки животных [11]. Информация о наиболее значимых функциональных кандидатах, частично или полностью локализованных в регионах CNV у разных видов сельскохозяйственных животных, в обобщенном виде представлена в обзоре [12].

В настоящее время гены-маркеры хозяйственно ценных признаков служат помощниками в отборе птицы для дальнейшего разведения и селекции с целью закрепления желательных генотипов в изучаемых породах кур. Разумеется, что можно подобрать генетические маркеры для некоторых признаков, но далеко не для всех, и в этой связи селекция по одним признакам будет более успешной, чем по другим. Что касается промышленных популяций кур, то специалисты в течение ряда десятилетий вели отбор по таким важнейшим признакам, как скорость роста и яйценоскость, поэтому понятно, что основные гены, которые могут оказывать заметное влияние на эти признаки, уже были определены, а значит, вероятность обнаружения вариантов маркера, оказывающего большое влияние на эти признаки, невелика. Более значительных успехов можно ожидать при проведении отбора на «трудные», из-за низкой наследуемости, признаки. К таким признакам можно отнести фертильность, устойчивость $\mathrm{K}$ ряду болезней и патогенов. В этом ключе появление новых возможностей для решения стоящих перед селекционерами задач с помощью генетического подхода можно считать большой удачей. Технология использования генетических маркеров призвана сыграть важную роль в дальнейшем развитии отечественного птицеводства в ближайшем будущем.

\section{Исследование ироведено ( рамках быполнения госу- дарственного задания Ми- нистерства науки и Gысие- 20 образования РФ по теме «Разработамь селекиионно- генетические методы по- бичиения быхода племенной и моварной продукиии от сельскохозяйстВенной пти- u,bl».}

\section{Литература}

1. Зиновьева Н.А., Багиров В.А., Гладырь Е.А., Осадчия О.Ю. Современные достижения и проблемы биотехнологии сельскохозяйственных животных. Аналитический обзор // С.-х. биология. - 2016. - Т. 51 . - №2. - С. 264-268. 2. Ефимов Д.Н., Емануйлова Ж.В., Журавлева Е.В., Егорова А.В., Фисинин В.И. Селекция птицы исходных линий породы плимутрок (Gallus gallus L.) с использованием маркерных генов к и k // С.-х. биология. - 2018. - Т. 53. №6. - С. $1162-1168$.

3. Баркова О.Ю. Обзор значимых локусов количественных признаков, ас- социированных с качеством скорлупы яиц кур // Птицеводство. - 2021 . №1. - С. 9-13.

4. Химанина Ю.А., Сазанова А.Л., Стекольникова В.А., Малевски Т., Ящак К., Сазанов А.А. Анализ экспрессии генов-кандидатов, контролирующих толщину скорлупы яйца у домашней курицы // С.-х. биология. 2008. - №6. - С. 40-43.

5. Кулибаба Р.А., Ляшенко Ю.В., Юрко П.С. Генетическая дифференциация пород кур украинской селекции с использованием различных типов молекулярно-генетических маркеров // С.-х. биология. - 2018. - Т. 53. №2. - C. 282-292.

6. Zhang G., Ding F., Wang J., Dai G., Xie K., Zhang L., Wang W., Zhou S. Polymorphism in exons of the myostatin gene and its relationship with body weight traits in the Bian chicken // Biochem. Genet. - 2011. - V. 49, No 1-2. P. 9-19.

7. Митрофанова О.В., Дементьева Н.В., Тыщенко В.И., Юрченко О.П., Вахрамеев А.Б. Связь генотипов по однонуклеотидным заменам в гене миостатина с показателями живой массы у кур Юрловской голосистой породы // Генетика и разведение животных. - 2015. №1 . - С. 39-42.

8. Крутикова А.А. Полиморфизм генов миостатина MSTN, пролактина PRL и рецептора D2 досрамина DRD2 у кур разного направления продуктивности: автореф. дис. ... канд. биол. наук. - Дубровицы, 2017. - 26 с.

9. Ларкина Т.А., Сазанова А.Л., Фомичев К.А., Баркова О.Ю., Сазанов А.А., Малевски Т., Ящак К. Изучение экспрессии генов-кандидатов массы абдоминального жира у домашней курицы (Gallus gallus) // Генетика. 2011. - T. 47. - №8. - С. 1140-1144.

10. Ларкина Т.А., Терлецкий В.П. Анализ связи мононуклеотидной замены (SNP) в регуляторной области гена PPARG с признаками «масса» и «содержание абдоминального жира» у кур // Изв. Оренбургского ГАУ. 2015. - T. 54. - №4. - С. 199-201.

11. Clop A., Vidal O., Amills M. Copy number variation in the genomes 
of domestic animals // Anim. Genet. 2012. - V. 43, No 5. - P. 503-517.

12. Кошкина О.А., Денискова Т.Е., Зиновьева Н.А. Вариация числа копий (CNV) как перспективный генетический маркер: распространение, методы валидации и гены-кандидаты в геномах сельскохозяйственных животных (обзор) // Агр. наука Евро-Северо-Востока. - 2020. - Т. 21 . - №4. - С. 355-368.
Для контакта с авторами:

Коршунова Людмила Георгиевна

E-mail: Ig@vnitip.ru

Карапетян Рубен Ваагнович

E-mail: ruben@vnitip.ru

\title{
The Use of the Genetic Methods Based on the DNA Markers of the Productive Traits in the Selection of Chicken
}

\author{
Korshunova L.G., Karapetyan R.V. \\ Federal Scientific Center "All-Russian Research and Technological Institute of Poultry" \\ of Russian Academy of Sciences
}

\begin{abstract}
Summary: The recent data on the use of the molecular genetic markers related to the productive and reproductive performance in the selection of chicken are reviewed. The importance of the research on the polymorphism in the genes potentially related to the productive traits for the development of Russian poultry production is emphasized. The prospective candidate genes directly affecting the productive traits and having polymorphic variations are listed. These marker genes can be used in the practical selection of chicken for the formation and maintenance of the desirable genotypes of Russian chicken breeds.
\end{abstract}

Keywords: chicken, productive traits, molecular genetic markers, genetic polymorphism, candidate genes, quantitative trait loci (QTL). 